\title{
Teachers enacting a technology-rich curriculum for emergent literacy
}

\author{
Amina Cviko $\cdot$ Susan McKenney $\cdot$ Joke Voogt
}

Published online: 13 July 2011

(C) The Author(s) 2011. This article is published with open access at Springerlink.com

\begin{abstract}
PictoPal is the name of a technology-rich curriculum with a focus on emergent literacy of Dutch kindergarteners. A case study design was used to examine teacher technology integration within PictoPal along with their perceptions about teaching/learning, technology and technology-based innovations. Observations were undertaken on pupils' engagement and teachers' technology integration within PictoPal. Interviews were used to examine teachers' perceptions. Pupils' emergent literacy learning was examined in a nonequivalent control quasi experimental design. Four kindergarten teachers and four classes $(N=95$ pupils) participated in the use of PictoPal. The findings suggest that a high extent of technology integration is related to: a developmental approach to teaching/ learning; positive attitudes and expectations towards technology-based innovations; and positive perceptions of support in stressful work conditions. Significant learning gains were found for the experimental group using PictoPal. High pupil learning gains were not related to a high extent of technology integration. Senior kindergarteners engaged to a higher extent with PictoPal than junior kindergarteners.
\end{abstract}

Keywords Technology integration - Technology rich learning environment . Emergent literacy $\cdot$ Kindergarten

\section{Introduction}

Over the last decade, the importance of improving language education in Dutch primary schools, and especially kindergartens, has been given increased attention. The Dutch

\footnotetext{
A. Cviko $(\bowtie) \cdot$ S. McKenney $\cdot$ J. Voogt

Department of Curriculum Design and Educational Innovation,

University of Twente, Enschede, The Netherlands

e-mail: a.cviko@utwente.nl

S. McKenney

e-mail: susan.mckenney@utwente.nl

J. Voogt

e-mail: j.m.voogt@utwente.nl
} 
Ministry of Education, Culture, and Science (MoECS) has initiated the formulation of national emergent literacy attainment targets (Verhoeven and Aarnoutse 1999). The formulation of the attainment targets aims to set the goals to be achieved, give teachers freedom in the design of their language curricula and responsibility for the achievement of their pupils (MoECS 1997).

Dutch kindergartens have junior and senior classes that are sometimes combined classrooms for children ages 4-6. In those two years, kindergarten pupils develop emergent literacy skills. The goal of the present study is to better understand the factors that influence teacher technology integration within PictoPal, a technology-rich curriculum with on and off computer emergent literacy activities. The study aims also to explore potential connections between teachers' technology integration, pupils' engagement in technology-supported activities and pupil learning.

Emergent literacy education in kindergarten contributes not only to learning to read and write, which is taught conventionally in Grade 1, but also to a broader area of literacy development as, for example, knowledge about the nature of language, writing, verbal ability, and the ability to process information. Young children's experiences with literacy are mostly gained in daily activities and their interaction with peers and adults (Cooper 1993), a process whereby children construct meaning. From Piaget's and Vygotsky's views on the role of play in the development of children's literacy, symbolic (or dramatic) play drives the child's symbol-making competence (Pellegrini and Galda 1993). From Piaget's perspective on learning, children practice during play individually and also in interaction with peers. A Vygotskian perspective emphasizes the adult (teacher)-child context with adults (teachers) stimulating social cooperation and interaction in learning, within a child's zone of proximal development. Both perspectives on the role of play in literacy provide a theoretical orientation for research involving child's emergent literacy development, which can be guided by teachers and supported by technology (e.g. Cassell 2004; McKenney and Voogt 2009).

In recent years, many Dutch kindergartens have invested in technology to support the curriculum. Various studies have shown positive effects of technology in supporting learning in emergent literacy development (e.g. Segers and Verhoeven 2002, 2005; McKenney and Voogt 2009; Van Scoter 2008; de Jong and Bus 2004). Meaningful literacy learning through engagement in literacy experiences and integration of technology in the classrooms with 4-6 old children has also been endorsed by the National Association for the Education of Young Children (NAEYC) and the International Reading Association (IRA) (NAEYC 1996, 2009; Neuman and Roskos 2005). Experts agree that technology use in kindergartens should not be isolated but rather integrated with classroom routines and activities for a learning environment to offer meaningful experiences for children (e.g. Clements et al. 1993; Amante 2007). Literacy learning is facilitated when children learn to use language for authentic purposes. Supported by technology, this could include writing a letter to a relative and posting a letter in a play corner (cf. Amante 2007; McKenney and Voogt 2009; Siraj-Blatchford and Whitebread 2003).

The assumption underlying this study is that the effectiveness of a technology-rich curriculum depends on how teachers integrate technology-supported learning with the interactions with peers and adults during classroom learning. Teachers play a central role in bridging the gap between: (a) the potential of technology to support learning as indicated by research; and (b) teachers' own choices about pedagogy and classroom practices. However, many primary school teachers struggle to integrate technology in the classroom (Ertmer 2005; Tondeur et al. 2007; Turbill 2001). One of the obstacles may be resistance to innovations due to their educational beliefs about teaching practice and technology 
(Zhao et al. 2002). Another powerful factor is how well or poorly software is aligned with the classroom curriculum (Whittier 2005).

\section{Teacher factors affecting technology integration}

The relationships between teacher perceptions, curriculum implementation and pupil learning are complex. Figure 1 shows the factors and relationships that were central in this study on the enactment of a technology-rich curriculum for early literacy. The remainder of this section describes the literature base that led to the conceptualization shown in Fig. 1.

Research on the role of teachers as enactors of a new curriculum in the classroom indicates that teacher perceptions of a curriculum affect curriculum implementation (e.g. Abrami et al. 2004; Cronin 1991). Teachers, who are provided with materials that portray the new curriculum, constantly adjust and adapt these curriculum materials to fit their teaching practice to the learning processes of their students (Remillard 1999, 2000; Grossman and Thompson 2008). Teachers as enactors of the curriculum construct the curriculum in their classrooms by adjusting and adapting it. Teacher's interpretations of the meaning and intents of the new curriculum can be regarded as a factor affecting actual implementation. Those interpretations might be related to teacher's perceptions and ideas about teaching/learning, technology and innovation (component B). The characteristics of a new curriculum (component $\mathrm{C}$ ) influences teacher considerations about its practicality.

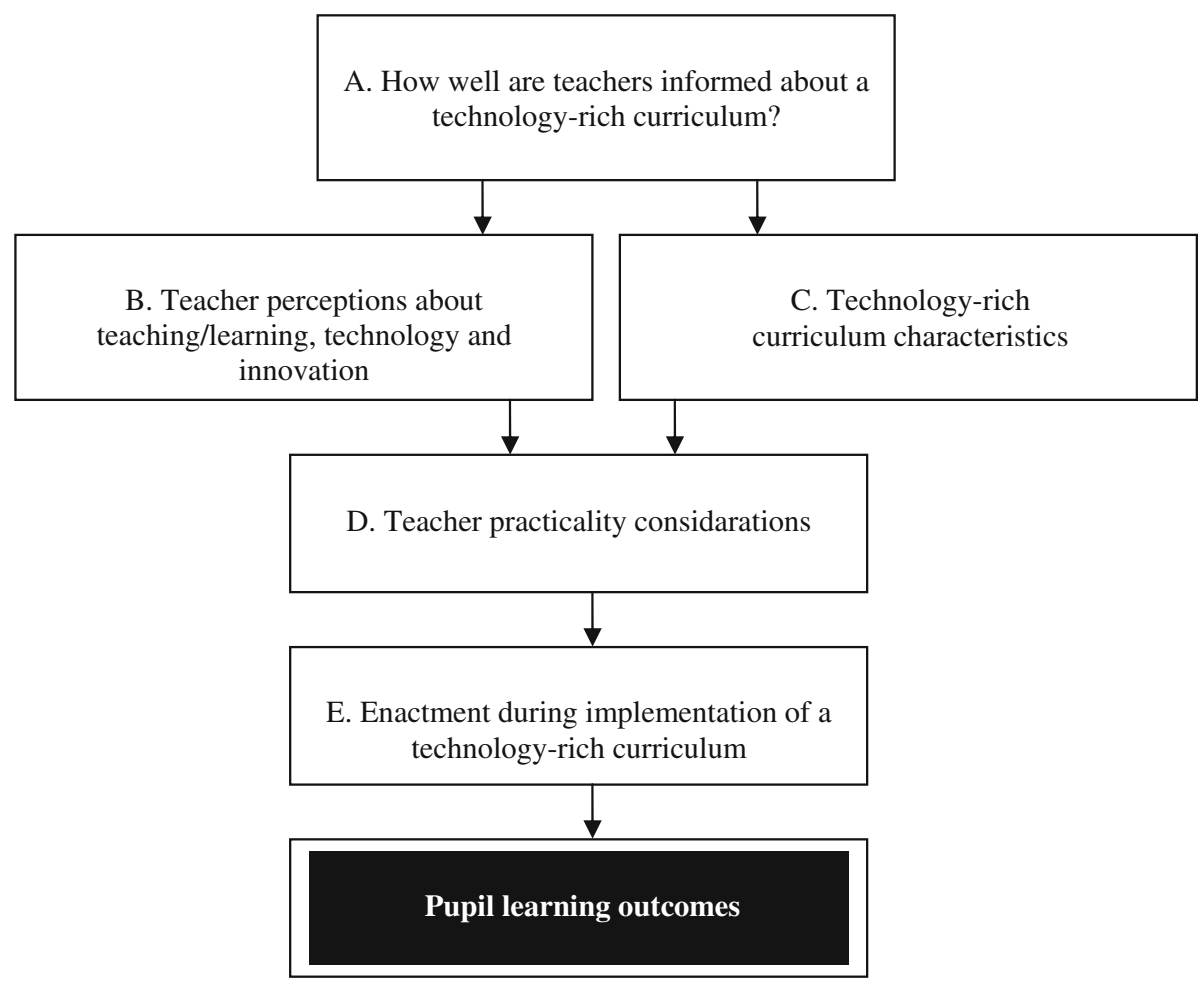

Fig. 1 Important influences on pupil learning 
Teachers might interpret the practicality of a curriculum differently and construct the enacted curriculum in a different way then was intended by its designers (component $\mathrm{C}$ ); and this may or may not affect pupils' learning outcomes.

Teacher perceptions concerning teaching/learning, technology and innovation (component B) influence enactment of a curriculum involving technology (component E) (Ertmer 2005; Zhao et al. 2002; Tondeur et al. 2008a; b; Inan and Lowther 2009). Teacher perceptions on teaching/learning, technology and innovation can originate from existing beliefs about pedagogy. For example, Hermans et al. (2008) found that teacher beliefs affect integrated classroom use of technology in primary schools. Teachers who hold constructivist beliefs reflecting a pupil-centered approach to teaching and learning, have a positive effect on integrated classroom use of technology, whereas teachers holding teacher-centered approaches to teaching and learning negatively influence integrated technology-use in the classroom. Also, Niederhauser and Stoddart (2001) found that teachers' pedagogical perspectives relate to the types of software used in classrooms. Specifically, K-2 teachers with a computer-centered approach to teaching favor use of skill-based software for young children.

Next to teachers' beliefs, the factors computer experience and attitudes are found to influence teachers' integrated use of technology (Hermans et al. 2008). Hermans et al. (2008) also found that the integration of technology in the classroom depends on the particular school context, suggesting that a particular school context can be regarded as a setting in which teachers' beliefs are shared. Teachers working in the same school tend to share similar beliefs about teaching and learning practices. Thus teacher's beliefs and the school context can influence integration of technology in his or her classroom practice. Successful implementation of innovations also depends on a teacher's decision-making based on his or her perceptions of what is practical and possible in a classroom setting (component D) (Doyle and Ponder 1978; Ertmer 1999).

Furthermore, previous research on the teacher as enactor of curriculum has shown that innovations around the integration of technology were most likely to succeed when: (a) the teachers were informed how to implement the innovation (component A) (how to use the technologies and how the innovation might support their teaching practice); (b) when the distance between innovative and existing teacher practices were small; and (c) when teachers could take small steps during the implementation of technology (Zhao et al. 2002). Also, the success of the implementation of technology innovation is determined by teachers' computer proficiency, knowledge about technology enabling conditions for teaching, the support offered to teachers (Inan and Lowther 2009; Koehler and Mishra 2008; Zhao et al. 2002), teacher willingness to learn from innovations; and their work conditions (Könings et al. 2006). Support to teachers (e.g. from administration, and availability of resources) seems to influence teachers' perception of technology, which in turn influences teachers' technology integration in classroom practice.

While literature points to the importance of teacher perceptions as influential on technology integration, little is known about how teacher perceptions on education, technology and innovations (component B) impact teacher technology integration and even less is known about if and how technology integration (component E) influences pupil learning outcomes. This study focuses on exploring (1) how kindergarten teacher perceptions on education, innovations and technology (component B) relate to teacher technology integration (component E); and (2) how teacher technology integration (component E) affects pupils learning. Further specification of the kindergarten teacher role in enacting a technology rich curriculum can help us understand how kindergarten teachers, with specific 
pedagogical perspectives, enact technology-based activities, and what implications can be drawn for the design of technology rich tools and curricula for emergent literacy.

Based on the framework given above, the PictoPal study reported here set out to examine kindergarten teachers' perceptions on teaching/learning, technology and innovations, their technology integration and pupil engagement and learning. Core constructs relating to the three variables of teacher perceptions about teaching/learning, technology and innovation are presented in Table 1.

The central question guiding this study was: How do teacher perceptions of teaching/ learning, technology and innovation impact integration of a technology-rich curriculum for emergent literacy and in turn, how does teacher technology integration of the curriculum impact pupil learning? To answer this research question, four sub-questions were formulated:

- Teacher perceptions: what are teachers' perceptions of teaching/learning, technology and innovations?

- Technology integration: to what extent do teachers integrate computer activities and classroom activities within a technology-rich curriculum?

- Pupil engagement: to what extent do pupils engage in on computer activities within the technology-rich curriculum?

- Pupil learning: what are pupil learning outcomes when teachers enact a technology-rich curriculum?

\section{PictoPal, a technology-rich curriculum for emergent literacy}

PictoPal is a technology-rich curriculum for emergent literacy with learning activities both on the computer and off the computer. PictoPal activities are designed to teach children about the communicative functions of written language. This important emergent literacy aspect is currently at risk of being usurped by the strong focus in the Dutch kindergarten curriculum on practicing technical (pre-) reading skills such as phonemic awareness, resulting in a potential gap in the curriculum. Not only is this area under emphasized in materials for learners, but few teaching materials are available to offer guidance on

Table 1 Description of variables as indicators for teachers' perceptions on teaching/learning, technology and innovation

\begin{tabular}{ll}
\hline Variable & Variable description \\
\hline $\begin{array}{l}\text { Vision on teaching/learning } \\
\begin{array}{l}\text { Attitudes towards computers (technology) } \\
\text { and experience with computers }\end{array}\end{array}$ & $\begin{array}{c}\text { What constitutes good teaching; roles of teachers and learners } \\
\text { Personal feelings about computer use; Experience with } \\
\text { technology in the kindergarten classroom; General } \\
\text { technology experience }\end{array}$ \\
$\begin{array}{l}\text { Attitudes and expectations towards } \\
\text { technology innovations }\end{array}$ & $\begin{array}{l}\text { Perceptions on technology innovations in kindergarten } \\
\text { classrooms; expectations for an technology -rich learning } \\
\text { environment }\end{array}$ \\
$\begin{array}{l}\text { Skills to implement the technology- } \\
\text { innovation }\end{array}$ & $\begin{array}{l}\text { learning environment in the kindergarten classroom } \\
\text { Perceptions on innovations as opportunities for learning }\end{array}$ \\
Willingness to learn & $\begin{array}{c}\text { Experience with (time) pressure in curriculum; support } \\
\text { offered to teachers }\end{array}$ \\
\hline
\end{tabular}


pedagogically appropriate strategies for teaching about the communicative functions of written language. PictoPal was created to address gaps in common early language curricula by focusing on a selection of the national attainment goals for emergent literacy: (1) functional reading and writing (writing and reading with a purpose); (2) function of written language (learning that written language as means of communication); (3) relationship between spoken and written language; and (4) language consciousness. The kindergarten teachers participating in this study identified the need for addressing these aspects of emergent literacy. They therefore expressed appreciation for the PictoPal focus and committed to a three year collaboration on incorporation of PictoPal in the kindergarten language curriculum.

A central tenet underlying PictoPal is the notion that children have an intrinsic drive to engage with the world around them (McKenney and Voogt 2009). PictoPal invites children to engage with written and spoken language, and to create their own written products. PictoPal focuses on forming linguistic concepts regarding the nature and function of written language by providing children with the opportunity to write their own texts and use their printed products in meaningful contexts (McKenney and Voogt 2009). The focus on meaning-making and use of written products is expressed through computer activities linked to off-computer activities. An example of an on-computer activity and an offcomputer activity is given in Figs. 2 and 3. In Fig. 2, children are co-creating the script for a weather forecast. In Fig. 3, they are 'broadcasting' the weather forecast to their classmates.

Computer activities were designed using Clicker $^{\circledR}$ software. Clicker ${ }^{\circledR}$ is a visual word processor with voice output. As seen in Fig. 2, the lower portion of the word processor consists of a grid with cells containing words and images; and the upper portion is a writing window. Clicking on the cells allows children to put words and images in the writing window and to hear the words spoken aloud. In addition, children can print their resulting written products. In this way, children's texts can be used in classroom activities in an authentic way. The connection between the computer activities and the classroom activities is made by teachers. Teachers create opportunities for children to use their written products in the classroom by introducing, organizing and arranging classroom applications (McKenney and Voogt 2009). A teacher manual supports the teacher with suggestions for the classroom activities. Table 2 gives examples of specific pedagogical strategies used in PictoPal to address national interim targets.

Fig. 2 On-computer activity: Composing the weather forecast

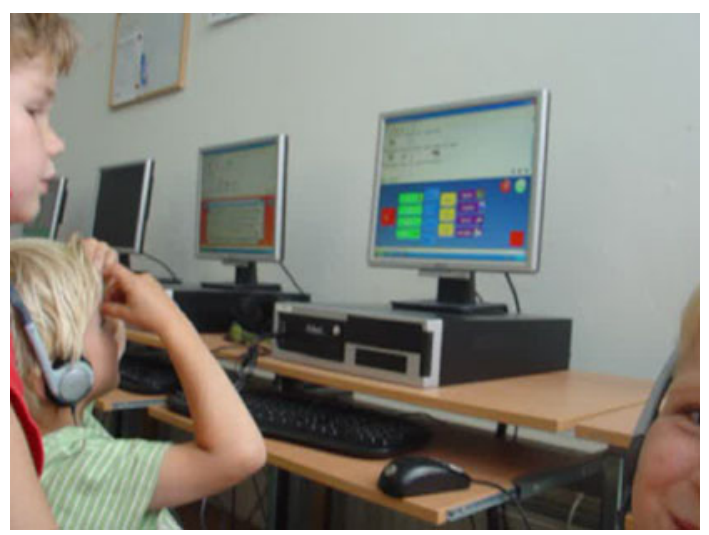


Fig. 3 Off-computer activity: Presenting the weather forecast

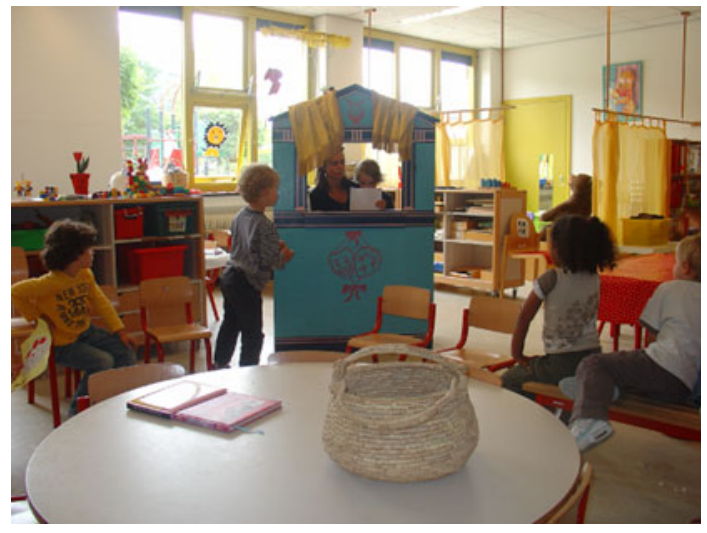

Table 2 Sample pedagogical strategies used in PictoPal

\section{National emergent literacy interim goals Sample pedagogical strategies used to meet different goals in PictoPal}

\section{Relationship between spoken and written language}

Language consciousness; words and sentences convey meaning

Functional writing; communicative purposes of reading and writing
1.1 Children listen to spoken words by clicking on written words with the right mouse button

1.2 When children (left mouse button) click on written words or pictograms, that word is 'written' in their own document (the computer types for them)

1.3 Children 'read' their printed products out loud

2.1 Children connect printed words to meaning by having pictograms placed above words.

2.2 Children review the meaning of what they have created when the computer 'reads' text back to them

(a) The computer reads each sentence when a period is entered.

(b) The computer reads any highlighted text (from one word to a whole document).

3.1 Each lesson is introduced by an activity that gives attention to the text genre and its purpose (stories are for entertainment; lists are to keep track of things, etc.)

3.2 Children 'use' printed products in authentic ways (e.g. letters are mailed; recipes are cooked, etc.)

\section{Methodology}

\section{Study design}

A case study design has been employed to investigate teacher technology integration within the technology-rich PictoPal curriculum. In this study, we applied a multiple data collection approach (Patton 2002) using a mix of quantitative and qualitative methods. The effects on integration and pupil learning were examined with quantitative data complimented with qualitative data on teacher perceptions to help explain those effects.

In this study, four cases (four kindergarten classrooms with four teachers) were studied with a common set of measures of (1) teachers' perceptions; (2) pupils' engagement in 
activities; (3) teachers' integration of on- and off-computer activities; and (4) pupils' emergent literacy proficiency. A comparative method was adopted, which involves representing each case separately and comparing them with each other (Patton 2002). To represent the relationships within the four cases, qualitative data on teachers' perceptions were used to interpret the quantitative data obtained for teachers' integration of on- and off-computer activities. Data on pupils' engagement and teachers' integration were used to interpret the data obtained for pupils' emergent literacy proficiency. In addition, comparisons of the four cases on the four measures were undertaken to reveal differential impact of the PictoPal curriculum on pupils' emergent literacy proficiency. Finally, a nonequivalent control group design was used to compare emergent literacy proficiency among pupils in the case study classes to a control group in which children were not exposed to PictoPal. In the study, the classroom teacher forms the unit of analysis for the teacher perspective variables, while the unit of analysis for the variables 'pupil engagement' and 'technology integration' and 'pupil learning outcomes' is formed by a kindergarten class.

\section{Context}

One primary school in a medium size town in the eastern part of the Netherlands participated in the study. This school consisted of three different campuses. The educational approach of the school can be described as adaptive teaching, which implies that pupils are encouraged to learn and work independently and that teachers strive to tailor education to individual pupil needs. In the kindergarten classrooms, teachers spend approximately $1 \mathrm{~h}$ a day specifically teaching literacy, using a language curriculum which has been adopted in many Dutch schools. This curriculum offers theme-based language activities for play corners and teacher guided classroom discussions. Additionally, an accompanying software program ("Treasure Chest") is offered, which relates to the learning goals, but not to the specific themes of the curriculum. The kindergarteners usually work 10 min a week with this software, individually and in pairs. The kindergarteners work on eight computers (two of them in the classroom and six of them placed outside the classroom). Teachers are supported when needed by two technology coordinators, concerned with updating and maintaining functionality of both hardware and software. The school principal provides support to teachers by offering opportunities for participating in in-service training and participating in teacher team discussions on kindergarten education.

\section{Participants}

The case study focused on the implementation of the PictoPal curriculum by four kindergarten teachers in one of this school's three campuses. The school suggested involving the four kindergarten teachers from one campus to participate in the study. When asked about the attention on communicative functions of written language in kindergarten emergent literacy curriculum, teachers from all campuses felt that there is a gap in the curriculum and expressed the need to address it, preferably with PictoPal. Teachers of the two other campuses originally wanted to explore PictoPal, but agreed to function as a control group during the study. They intended to start using PictoPal as soon as the research was finished. The four teachers forming the experimental group are native Dutch and are representative of average Dutch kindergarten teachers. Also, most pupils participating in this study come from (upper) middle class native Dutch neighborhoods. 
In the kindergarten classrooms of the other two campuses, the teachers used "Treasure Chest" as their language arts curriculum. These kindergarten classes served as a control group for this study. The group working with PictoPal consisted of 95 children $(n=95)$, mean age 65 months old (64 boys, and 51 girls). Kindergarteners from the other two campuses consisted of 73 children ( $n=73$ ), mean age 65 months ( 45 boys and 28 girls). To investigate the learning outcomes of pupils working with PictoPal, a nonequivalent control group design was used. All 168 pupils were pre- and post-tested on emergent literacy. The similarity of the groups concerning language skills was determined by scores on a national language test for kindergarten pupils. PictoPal was implemented in two junior kindergarten classrooms (1a and 1b) and two senior kindergarten classrooms ( $2 \mathrm{a}$ and $2 \mathrm{~b}$ ). The junior kindergarten classes consisted of pupils aged 4-5 years and the senior kindergarten classes had pupils aged 5-6 years. Table 3 presents an overview of the distribution of pupils in the four classrooms. Four female teachers were involved in the implementation of PictoPal in their classroom.

\section{Instruments}

\section{Interviews}

Data were collected on six constructs related to the three variables of teacher perceptions about teaching/learning, technology and innovation, as well as the teachers' current teaching context. A semi-structured interview scheme was used, which consisted of questions regarding the context of teaching in the kindergarten and questions related to (1) teaching/learning (e.g. visions about teaching/learning); (2) technology (e.g. attitudes, experiences and expectations regarding technology use); and (3) innovation (e.g. skills to implement PictoPal, willingness to learn, and work conditions). An example of the questions related to attitudes towards computers is: "How would you describe your feelings about using technology in your classroom?"

\section{Observation checklist}

The Integration Checklist (Verseput 2008) was used to structure observation of pupil engagement during on-computer activities and teachers' integration of PictoPal, including both on- and off-computer activities. The Integration Checklist consists of 8 items measuring the extent of engagement and 12 items measuring the extent of integration of onand off-computer activities. The 8 items measure the extent of pupil engagement in computer activities related to following topics (one item each): (1) group work; (2) collaborative work; (3) helping peers; (4) pupil activity; (5) individual work (6) requesting support (7) conversing about the process; and (8) conversing about the product.

Table 3 Teaching experiences (in years), number of pupils, gender and mean age (in months) of pupils at the start of PictoPal per classroom

\begin{tabular}{llllrl}
\hline & Years of experience & $n$ & Boys & Girls & Mean age \\
\hline Junior classroom 1a, teacher Alice & 20 & 19 & 11 & 8 & 57 \\
Junior classroom 1b, teacher Carol & 10 & 24 & 13 & 11 & 58 \\
Senior classroom 2a, teacher Diana & 12 & 27 & 13 & 14 & 70 \\
Senior classroom 2b, teacher Fiona & 33 & 25 & 14 & 11 & 71 \\
\hline
\end{tabular}


An example of item 8 is: "Pupils talk about the printed texts they created during their computer activity."

Items (one per topic) measuring the extent of integration of on- and off-computer activities relate to the topics: (1) involving pupils; (2) initiating listening; (3) initiating speaking; (4) initiating writing; (5) initiating reading; (6) play with writings; (7) initiating activity; (8) initiating collaboration; (9) initiating individual work; (10) providing support; (11) initiating talk about the process; and (12) initiating talk about the product. An example of item 12 is: "The teacher creates the opportunity for pupils to talk about their products."

The items were measured on a 3-point scale, with 0 indicating the target behavior is absent, .5 indicating some extent of the target behavior is observable, and 1 indicating a great extent of the target behavior is observable. The inter-rater reliability for the raters, who observed and rated pupils engagement and teacher integration within two activities, was found to be Cohen's kappa $=.67(p<.001), 95 \%$ CI $(.375-.966)$, indicating a substantial agreement.

\section{Emergent literacy test}

To measure pupil emergent literacy proficiency, the emergent literacy test for 4-5 year olds (McKenney and Voogt 2006) was used. The test was administered prior to the implementation of PictoPal and after the eight-week period in which pupils worked with PictoPal. The test consists of 14 items measuring the sub-set of emergent literacy skills related to the functions of written language, also including functional reading and writing, and connecting spoken and written language. An example item is the following task, aimed to determine if a child knows what writing is: (1) The researcher sets out color pencils, a pen, paper, scissors, a coloring page, a book, a spoon, a postcard and a grocery list; (2) the researcher presents the items to the child with an open arm gesture and says, "Can you pretend that you are writing something?" The item is scored as correct if the child takes either a pencil or a pen and a sheet of paper, and does or imitates the act of writing.

The items were scored on a two-point scale $(2=$ correct; $1=$ not correct $)$. Cronbach's alpha was .76 on the pre-test and .87 on the post-test. The pre-test scores on the emergent literacy test correlated significantly with the pupils' scores on the national language proficiency test $(\mathrm{rpb}=.52, p<.05)$. The correlation between the two tests suggests that the emergent literacy test for 4-6 year olds measures linguistic skills in children. The national language proficiency test measures two aspects related to conceptual consciousness of language: passive vocabulary; and listening (Van Kuyk and Kamphuis 2001). This test also measures some aspects of emergent literacy (meta-linguistic consciousness) which are: sound and rhyme; writing orientation; hearing the first and last word in a sentence; and synthesizing sounds. The specific aspects of emergent literacy measured by the two tests do not overlap, but both measure elements described in the national interim goals for emergent literacy.

Data analysis

For this study, we adopted a qualitative comparative method involving examination of cases separately along common variables, followed by a cross-case analysis (Patton 2002; Miles and Huberman 1994). The data on teachers' perceptions were content analyzed within each case to understand the particular cases by summarizing teachers' interview responses into groups, attaching a content code to each teacher's response reflecting the core of the response. The comparison of perceptions across the four cases involved 
scanning the responses for commonalities and shared perceptions, thereby mitigating the risk of forcing cases into the same categories (Miles and Huberman 1994). Each teacher's perceptions were then compared to the data on her technology integration. The qualitative data analysis was conducted by two researchers: one researcher grouped and coded the interview responses; twice, the other researcher critically reviewed the content and meaning of the teacher response analysis conducted by the first researcher.

The data on teacher technology integration was analyzed using analysis of variance (ANOVA) to test the hypothesis that there were no differences on technology integration between the four cases. On the basis of the data distribution on technology integration, the means of the four cases were assigned a group label reflecting the extent of PictoPal technology integration expressed as low, medium or high. The same three labels were used to characterize extents of pupil engagement during on-computer activities. The relative position of the means for both sets of data were determined by assigning the scores below the 33.3rd percentile into 'low' group, the scores above or equivalent to the 66.7th percentile to a 'high' group, and the scores below the 66.7th percentile but at or above the 33.3rd percentile to the 'medium' group. Regression analysis was used to examine how the extents of teacher integration and the extent of pupil engagement were predicted by the length of time they worked within PictoPal. Following analysis of the data on the technology integration and pupil engagement, teachers' perceptions and their technology integration were compared qualitatively, by representing each case as a combination of relationships between perceptions and technology integration.

Pupil learning was analyzed using analysis of covariance (ANCOVA). We tested the hypothesis that the means of the emergent literacy pre- and post-test score differences did not differ between the control and the quasi-experimental group when adjusted for the pupils' scores on the national language test. Following the analysis, the extent of the integration of on- and off-computer activities and pupils' engagement in computer activities was qualitatively compared with the results on pupils' learning outcomes in order to be able to explain differences in pupil learning outcomes by teacher technology integration. In a cross-case analysis we tried to explain teacher technology integration by teachers' perceptions.

\section{Procedure}

The implementation of PictoPal started with a one-day workshop provided to teachers by the researchers as an introduction to PictoPal. The aim of the workshop was to create dialog with teachers about the content of the curriculum material (computer activities and classroom activities) and the practical organization of PictoPal. The curriculum material was a PictoPal module centering on the theme of springtime. It consisted of eight activities all linked to the central theme of spring, structured to expose children to different text types (lists, report/forecast, instructions, stories, letters, poems and invitations). At the same time, the off-computer applications were designed to bring the functions of the different text types to life in meaningful ways for the children. Figures 1 and 2 show the on- and offcomputer activities associated with 'writing' and 'broadcasting' the weather forecast.

Prior to the implementation of PictoPal, interviews were conducted with four teachers on their perceptions of teaching/learning, technology and innovation. The interviews lasted approximately $1 \mathrm{~h}$ per teacher. All interviews were audio taped and transcribed verbatim. The resulting phrases were coded. Also, prior to PictoPal implementation all pupils $(N=168)$ were pretested using the previously described emergent literacy test 
(McKenney and Voogt 2006). In addition, pupils' scores on the national language proficiency test were gathered.

For the duration of the PictoPal implementation (eight weeks), teachers implemented three inter-linked activities a week: an introductory activity, on-computer activity, and offcomputer activity. All teachers executed the eight introductory- and off-computer activities. Guidance of kindergarteners during on-computer activities was provided by pupils from the sixth grade. The time in which pupils engaged in on-computer activities ranged between $10 \mathrm{~min}$ for the first three activities to $15 \mathrm{~min}$ for the seventh and eighth computer activity. For each PictoPal on-computer activity in each class different pupils were chosen to form a pair to work together. During 10-15 min of each on-computer activity we observed one pair of pupils from each of the four classes. The observation data gathered during eight on-computer activities was based on 16 pupils per class, which is representative for the four classes with 18-26 pupils. One researcher and one research assistant gathered 32 observations on engagement of pupils during all eight on-computer activities from four classes.

The pupils' on-computer activities were followed by off-computer activities in which pupils used the prints of their computer-generated texts. Also, for the duration of the PictoPal implementation, the eight off-computer activities were observed in all 4 kindergarten classrooms. Observations focused on teacher integration of the on- and off-computer activities. Each observation lasted approximately $20 \mathrm{~min}$. The data on integration of on- and off-computer activities constituted 32 observations of eight integrated activities taught by teachers in four kindergarten classrooms. After PictoPal implementation, all pupils $(N=168)$ were post-tested with the same emergent literacy test as was used in the pre-test.

\section{Results}

The results are presented in the order of research questions to address (1) teacher perceptions (2) teacher technology integration, (3) pupil engagement and (4) pupil learning.

\section{Teacher perceptions}

In a cross case analysis we compared the perceptions of the teachers on the six variables. The results are presented in Table 4.

The results of the cross-case analysis on teachers' perceptions (Table 4) showed that the four teachers differed somewhat in their perceptions about teaching. Particularly Diana expressed having a more developmental approach to teaching expressing her view on teaching as 'helping children by bringing them a step further in their language development by letting them experience language in an enjoyable and a playful way, and also helping children in their social-emotional, motor, and cognitive development.

While the other teachers emphasized facilitative approach to teaching, for example Carol who expressed her view on teaching: 'Well, anyway creating a stable environment to let children feel secure. And from there, they can learn. Of course, from there on, it will be incrementally expanded.'

With respect to their attitudes towards computers, all four teachers were rather positive, but Carol seemed to be a little bit more reserved about the use of computers for teaching kindergarteners explaining that 
Table 4 Cross-case analysis of teachers' perceptions

\begin{tabular}{|c|c|c|c|c|}
\hline Variable & $\begin{array}{l}\text { Classroom 1a } \\
\text { Alice }\end{array}$ & $\begin{array}{l}\text { Classroom 1b } \\
\text { Carol }\end{array}$ & $\begin{array}{l}\text { Classroom 2a } \\
\text { Diana }\end{array}$ & $\begin{array}{l}\text { Classroom 2b } \\
\text { Fiona }\end{array}$ \\
\hline \multirow{2}{*}{$\begin{array}{l}\text { Teacher } \\
\text { perceptions } \\
\text { on teaching/ } \\
\text { learning }\end{array}$} & \multirow[t]{2}{*}{$\begin{array}{l}\text { Adaptive } \\
\text { teaching }\end{array}$} & Adaptive teaching & $\begin{array}{l}\text { Developmental } \\
\text { teaching }\end{array}$ & Adaptive teaching \\
\hline & & $\begin{array}{l}\text { Viewing safe } \\
\text { environment as } \\
\text { condition for } \\
\text { learning }\end{array}$ & & $\begin{array}{l}\text { Viewing safe } \\
\text { environment as } \\
\text { condition for learning }\end{array}$ \\
\hline \multirow{3}{*}{$\begin{array}{l}\text { Attitudes } \\
\text { towards and } \\
\text { experience } \\
\text { with } \\
\text { computers }\end{array}$} & $\begin{array}{l}\text { Positive attitudes } \\
\text { towards } \\
\text { computers }\end{array}$ & $\begin{array}{l}\text { Positive experiences } \\
\text { own use }\end{array}$ & $\begin{array}{l}\text { Positive attitudes } \\
\text { towards } \\
\text { computers }\end{array}$ & $\begin{array}{l}\text { Positive attitudes } \\
\text { towards computers }\end{array}$ \\
\hline & $\begin{array}{l}\text { Positive } \\
\text { experiences } \\
\text { own use }\end{array}$ & $\begin{array}{l}\text { Difficulty of } \\
\text { computer programs } \\
\text { influence computer } \\
\text { use in the class }\end{array}$ & $\begin{array}{l}\text { Use of computers } \\
\text { as a tool } \\
\text { supporting } \\
\text { learning }\end{array}$ & $\begin{array}{l}\text { Positive experiences } \\
\text { own use }\end{array}$ \\
\hline & & & $\begin{array}{l}\text { Need for } \\
\text { professional } \\
\text { development on } \\
\text { how to deal } \\
\text { with computers } \\
\text { as a tool }\end{array}$ & \\
\hline \multirow[t]{3}{*}{$\begin{array}{l}\text { Attitudes } \\
\text { towards and } \\
\text { expectations } \\
\text { of } \\
\text { technology- } \\
\text { based } \\
\text { innovations }\end{array}$} & $\begin{array}{l}\text { Positive attitude } \\
\text { towards } \\
\text { technology- } \\
\text { based } \\
\text { innovations }\end{array}$ & $\begin{array}{l}\text { Positive, but } \\
\text { technology-based } \\
\text { innovations are not } \\
\text { the main goal for } \\
\text { kindergarten. }\end{array}$ & $\begin{array}{l}\text { Positive attitudes } \\
\text { towards } \\
\text { technology- } \\
\text { based } \\
\text { innovations }\end{array}$ & $\begin{array}{l}\text { Positive, but } \\
\text { technology-based } \\
\text { innovations can only } \\
\text { work if the teacher } \\
\text { knows the innovation } \\
\text { before } \\
\text { implementation }\end{array}$ \\
\hline & \multirow[t]{2}{*}{$\begin{array}{l}\text { Investment of } \\
\text { effort during } \\
\text { implementation }\end{array}$} & $\begin{array}{l}\text { Investment of effort } \\
\text { during } \\
\text { implementation }\end{array}$ & $\begin{array}{l}\text { Expectation of } \\
\text { successful } \\
\text { implementation } \\
\text { of PictoPal }\end{array}$ & $\begin{array}{l}\text { Investment of effort } \\
\text { during } \\
\text { implementation }\end{array}$ \\
\hline & & $\begin{array}{l}\text { Expectation of } \\
\text { successful } \\
\text { implementation of } \\
\text { PictoPal }\end{array}$ & & $\begin{array}{l}\text { Expectation of } \\
\text { successful } \\
\text { implementation of } \\
\text { PictoPal }\end{array}$ \\
\hline $\begin{array}{l}\text { Skills to } \\
\text { implement } \\
\text { the } \\
\text { technology- } \\
\text { innovation }\end{array}$ & $\begin{array}{l}\text { Confidence in } \\
\text { being } \\
\text { competent to } \\
\text { implement } \\
\text { PictoPal }\end{array}$ & $\begin{array}{l}\text { Confidence in being } \\
\text { competent to } \\
\text { implement } \\
\text { PictoPal; does not } \\
\text { feel at ease with } \\
\text { printers }\end{array}$ & $\begin{array}{l}\text { Confidence in } \\
\text { being } \\
\text { competent to } \\
\text { implement } \\
\text { PictoPal }\end{array}$ & $\begin{array}{l}\text { Confidence in being } \\
\text { competent to } \\
\text { implement PictoPal }\end{array}$ \\
\hline $\begin{array}{l}\text { Willingness to } \\
\text { learn }\end{array}$ & $\begin{array}{l}\text { Wants to learn } \\
\text { from PictoPal }\end{array}$ & $\begin{array}{l}\text { Wants to learn from } \\
\text { PictoPal }\end{array}$ & $\begin{array}{l}\text { Wants to learn } \\
\text { from PictoPal }\end{array}$ & $\begin{array}{l}\text { Wants to learn from } \\
\text { PictoPal }\end{array}$ \\
\hline & $\begin{array}{l}\text { Learning at own } \\
\text { workplace by } \\
\text { implementing } \\
\text { the innovation } \\
\text { Time pressure in } \\
\text { teaching }\end{array}$ & $\begin{array}{l}\text { Learning at own } \\
\text { workplace by } \\
\text { implementing the } \\
\text { innovation }\end{array}$ & $\begin{array}{l}\text { Learning at own } \\
\text { workplace by } \\
\text { implementing } \\
\text { the innovation }\end{array}$ & $\begin{array}{l}\text { Learning about } \\
\text { innovations in courses } \\
\text { outside the school and } \\
\text { from workshops of } \\
\text { the technology } \\
\text { coordinators }\end{array}$ \\
\hline
\end{tabular}


Table 4 continued

\begin{tabular}{|c|c|c|c|c|}
\hline Variable & $\begin{array}{l}\text { Classroom 1a } \\
\text { Alice }\end{array}$ & $\begin{array}{l}\text { Classroom } 1 \mathrm{~b} \\
\text { Carol }\end{array}$ & $\begin{array}{l}\text { Classroom } 2 \mathrm{a} \\
\text { Diana }\end{array}$ & $\begin{array}{l}\text { Classroom } 2 b \\
\text { Fiona }\end{array}$ \\
\hline & & & $\begin{array}{l}\text { Experiencing to } \\
\text { receive support } \\
\text { on time pressure } \\
\text { from principal }\end{array}$ & $\begin{array}{l}\text { Experiencing support } \\
\text { on technology } \\
\text { applications by the } \\
\text { technology } \\
\text { coordinators }\end{array}$ \\
\hline
\end{tabular}

It depends on the software used. In general children like it, but if software appears to be difficult then you [as a teacher] have to offer a lot of help, which is sometimes very difficult.

When we asked teachers about their attitudes towards technology-based innovations, Carol seemed to be somewhat reserved. All four teachers were fairly positive about PictoPal as an innovation, although Alice, Carol and Fiona expected to invest time in the implementation of PictoPal. The four teachers felt confident that they have the skills to implement PictoPal and want to learn from the experience. Only Fiona did not feel the pressure of time when teaching the kindergarten curriculum, the other three teachers experienced time pressure to teach the kindergarten curriculum. Diana reported that she experienced support from the principal with regard to time pressure.

Teacher integration of on- and off-computer activities

Integration of on- and off -computer activities of four teachers was compared in order to reveal any differential impact of teacher integration on pupils' emergent literacy proficiency. An ANOVA with integration of on- and off-computer activities as a dependent variable and classroom with 4 levels as independent variable showed a difference for level $F(3,28)=3.035, p<.05, \eta^{2}=.25$. The senior kindergarten teacher from classroom $2 \mathrm{a}$ integrated on- and off-computer activities to a significantly higher extent $M=7.06$, $S D=2.24$ than the teacher teaching in the junior kindergarten classroom $1 \mathrm{~b} M=3.63$, $S D=1.87$. Teachers of the senior kindergarten classes ( $2 \mathrm{a}$ and $2 \mathrm{~b}) M=6.19, S D=2.74$ integrated the on- and off- computer activities to a significantly higher extent compared to teachers of the junior kindergarten classes ( $1 \mathrm{a}$ and $1 \mathrm{~b}) M=4.28, S D=1.91, t(30)=2.28$, $p=.03, d=.83$. Table 5 summarizes the means and standard deviations found for teacher integration of on- and off-computer activities.

The distribution of the observation data, shown in Fig. 4 illustrates how teachers scored on the 12 items measuring the integration of the on- and off-computer activities. In Fig. 5, the extent of integration is shown during the time that teachers worked with PictoPal.

Diana (2a) did not score lower than other teachers on integration items, except on initiating speaking. Alice (1a) and Carol (1b) scored very low on initiating conversations about the process of off-computer activities and initiating collaboration. Carol (1b) and Fiona (2b) scored low on involving pupils in activities.

A significant proportion of variance in integration can be explained by the time Carol (1b), Diana (2a), and Fiona (2b) worked within PictoPal, respectively $R^{2}=.74, F(1$, $6)=16.96, p<.05 ; R^{2}=.54, F(1,6)=7.03, p<.05$, and $R^{2}=.75, F(1,6)=17.50$, $p<.05$. Although the extent of Alice's (1a) integration increases over time, no significant 
Table 5 Means and standard deviations of pupil engagement in on-computer activities and teachers integrated teaching of on and off computer activities

\begin{tabular}{|c|c|c|c|c|}
\hline & \multicolumn{2}{|c|}{$\begin{array}{l}\text { Junior kindergarten } \\
\text { classrooms }\end{array}$} & \multicolumn{2}{|c|}{$\begin{array}{l}\text { Senior kindergarten } \\
\text { classrooms }\end{array}$} \\
\hline & $\begin{array}{l}\text { Classroom } \\
\text { la } \\
\text { (Alice) }\end{array}$ & $\begin{array}{l}\text { Classroom } \\
1 \mathrm{~b} \\
(\text { Carol) }\end{array}$ & $\begin{array}{l}\text { Classroom } \\
2 \mathrm{a} \\
\text { (Diana) }\end{array}$ & $\begin{array}{l}\text { Classroom } \\
2 \mathrm{~b} \\
\text { (Fiona) }\end{array}$ \\
\hline Engagement in on- computer activities $(n=8)$ & $\begin{array}{l}3.81(1.22) \\
\mathrm{L}\end{array}$ & $\begin{array}{l}3.56(1.27) \\
\mathrm{L}\end{array}$ & $\begin{array}{c}4.56(1.29) \\
\mathrm{M}\end{array}$ & $\begin{array}{l}5.50(1.46) \\
\mathrm{H}\end{array}$ \\
\hline $\begin{array}{l}\text { Integrated teaching on- and off-computer } \\
\text { activities }(n=8)\end{array}$ & $\begin{array}{l}4.94(1.82) \\
\mathrm{M}\end{array}$ & $\begin{array}{l}3.63(1.86) \\
\mathrm{L}\end{array}$ & $\begin{array}{l}7.06(2.24) \\
H\end{array}$ & $\begin{array}{l}5.31(3.06) \\
\mathrm{M}\end{array}$ \\
\hline
\end{tabular}

Note: Pupil engagement on computer maximum score 8; Integrated on- and off-computer activities maximum score $12 ; \mathrm{L}=$ low; $M=$ medium; $\mathrm{H}=$ high, are indicators of the relative position of means in the observed range of scores

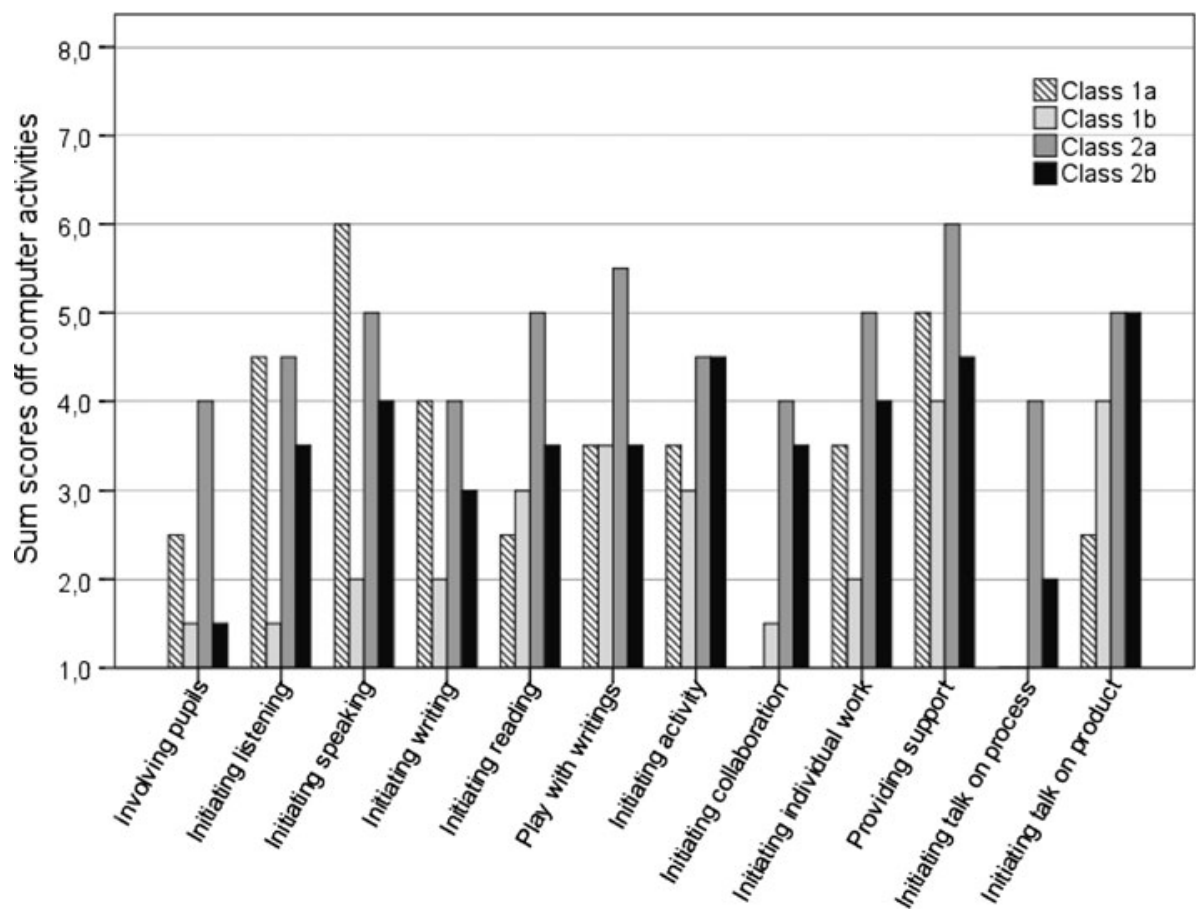

Fig. 4 Distribution of observation data on the items of the integration of the on- and off-computer activities

correlation was found between her time working within PictoPal and the extent of integration.

Pupil engagement in on-computer activities

An ANOVA with engagement in computer activities as a dependent variable and classroom with 4 levels (class $1 \mathrm{a}$, class $1 \mathrm{~b}$, class $2 \mathrm{a}$ and class $2 \mathrm{~b}$ ) as an independent variable 


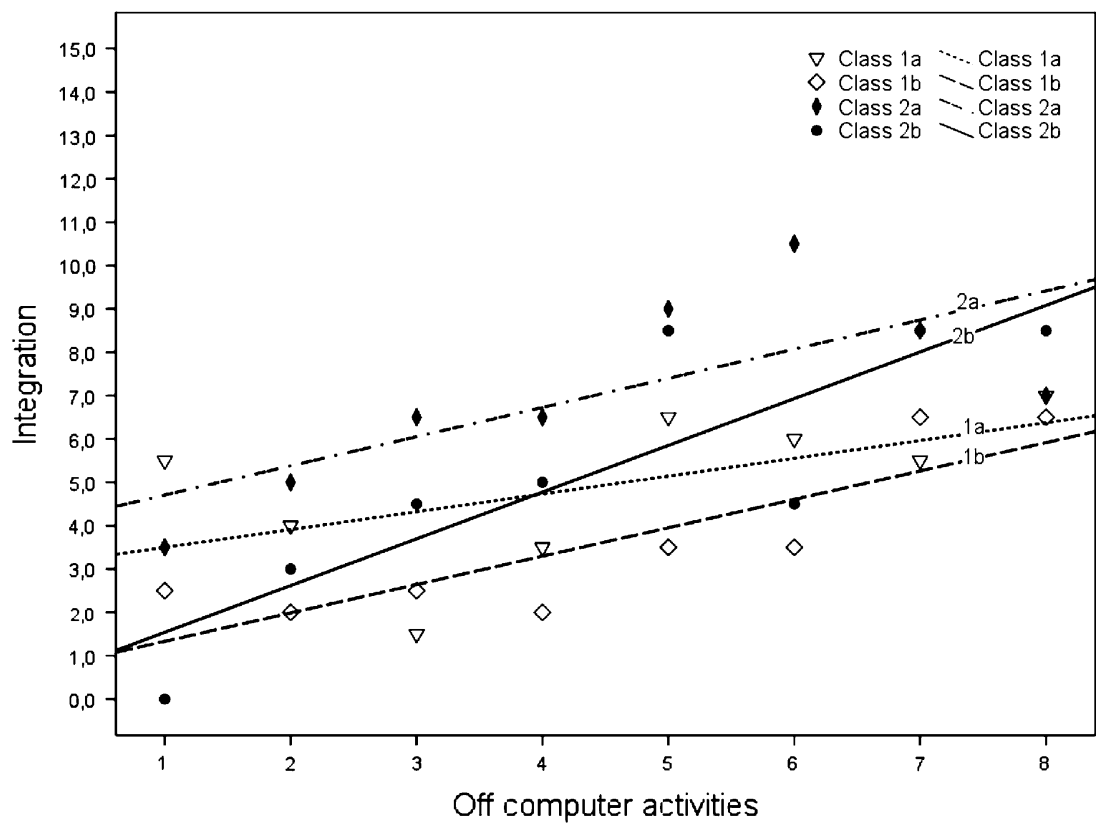

Fig. 5 The integration of the on- and off-computer activities in each class during 8 on-and off computer activities

showed a significant difference for the level $F(3,28)=3.511, p<.05, \eta^{2}=.27$. Senior class pupils (2b) $M=5.50, S D=1.46$ were significantly higher engaged in computer activities than the junior class pupils $1 \mathrm{~b} M=3.56, S D=1.27$. Senior class pupils ( $2 \mathrm{a}$ and 2b) $M=6.19, S D=2.74$ engaged to a higher extent in computer activities than junior class pupils ( $1 \mathrm{a}$ and $1 \mathrm{~b}$ ), $t(30)=2.88, p=.01, d=1.29$. Table 5 summarizes the means and standard deviations found for pupil engagement.

The distribution of the observation scores on the separate items of pupil engagement in on-computer activities is shown in Fig. 6. As Fig. 6 illustrates, the differences in pupil engagement per classroom appear to be around collaboration, helping peers, conversing on process and conversing on product during the computer activities.

In Fig. 7, the extent of pupil engagement is shown over the time that pupils of the four classrooms worked within PictoPal. The successive on-computer activities explained a significant proportion of variance in pupils engagement scores for classes $1 \mathrm{a}, 1 \mathrm{~b}, 2 \mathrm{a}$ and $2 \mathrm{~b}$, respectively $R^{2}=.72, F(1,6)=15.17, p<.05 ; R^{2}=.49, F(1,6)=5.85, p<.05$; $R^{2}=.83, F(1,6)=29.96, p<.05$ and $R^{2}=.91, F(1,6)=64.00, p<.05$.

Pupil learning

Table 6 shows the means, standard deviations in the pre-and post-test for the experimental and control group, and also the learning gains and effect sizes of the learning gains (Cohen's d) for both groups. An ANCOVA with pre-post differences as dependent variable and group (experimental and control group) as independent variable, and national test language proficiency as a covariate showed a significant difference for group on emergent literacy $F(1,159)=14.508, p<.05, \eta^{2}=.08$. The learning gains of the pupils in the 


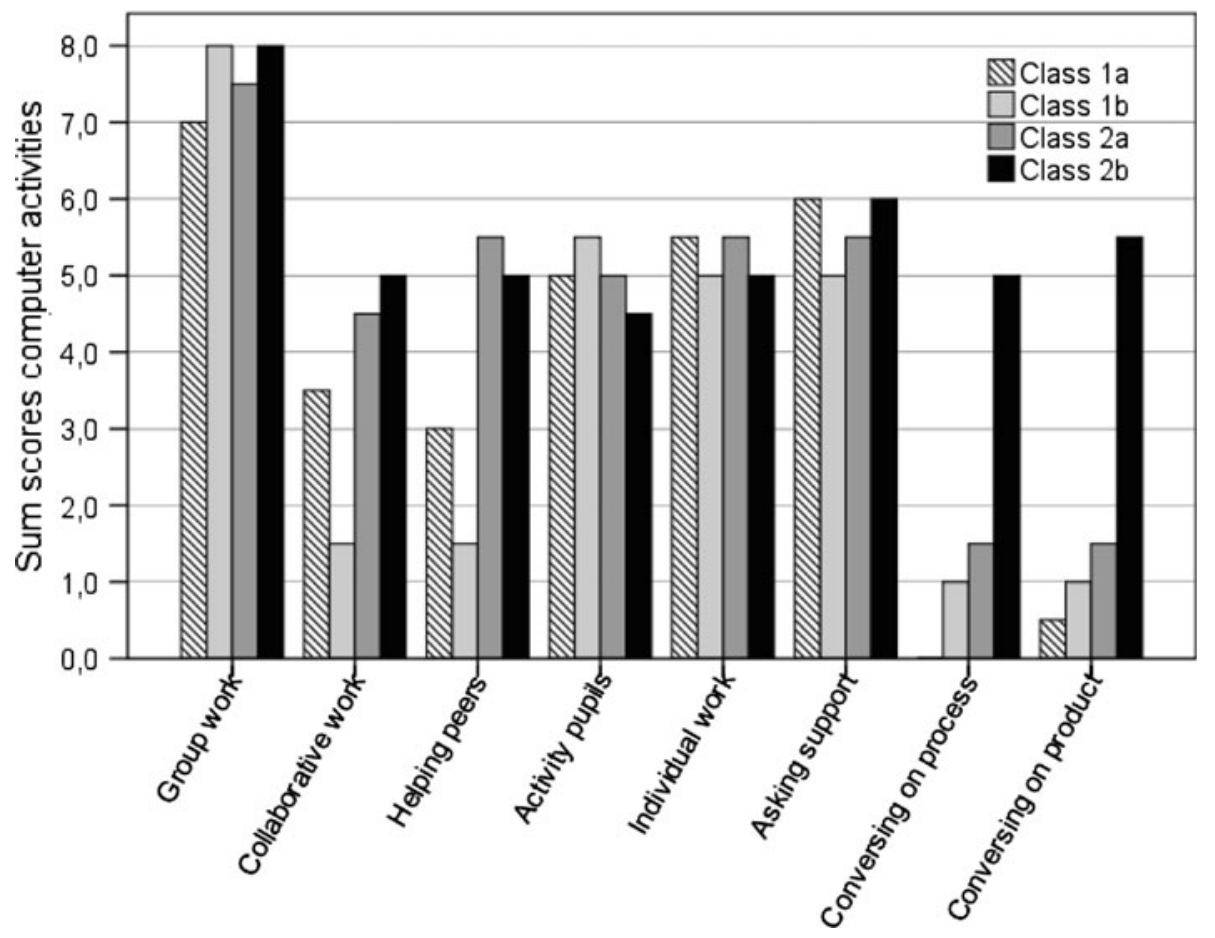

Fig. 6 Distribution of observation data on the items of pupil engagement in computer activities

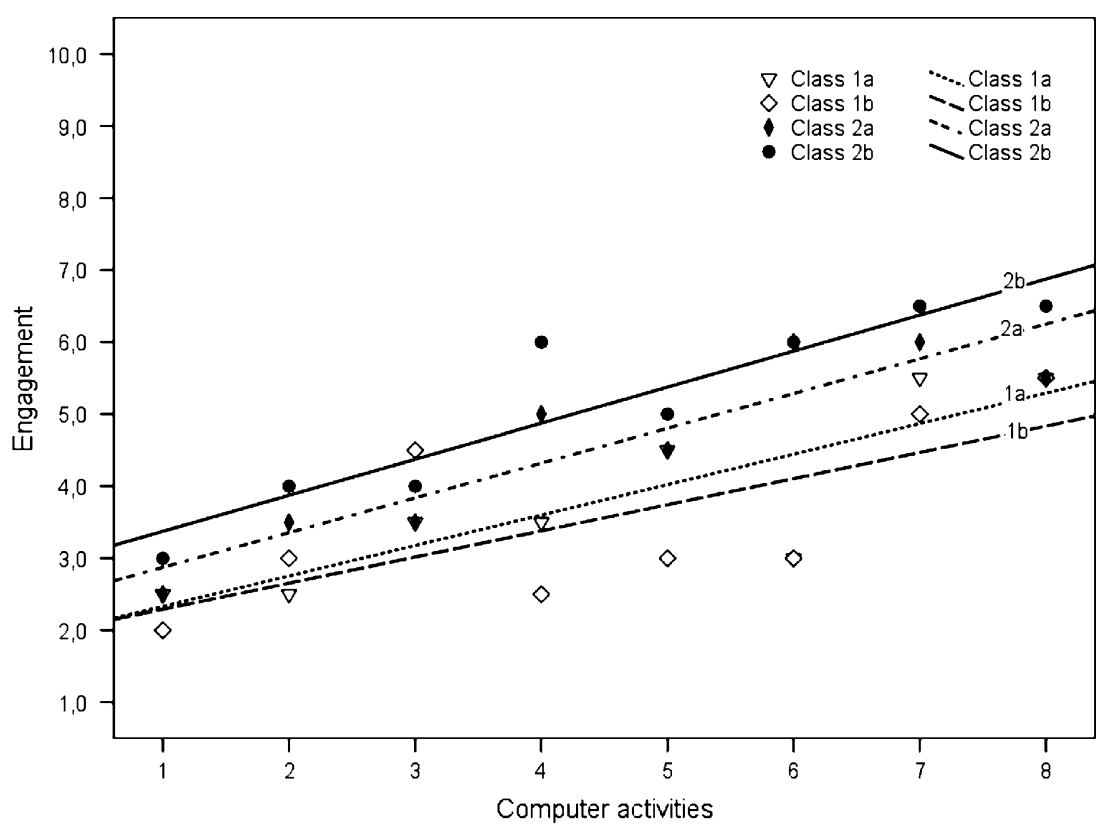

Fig. 7 Pupil engagement in each class during the 8 computer activities 


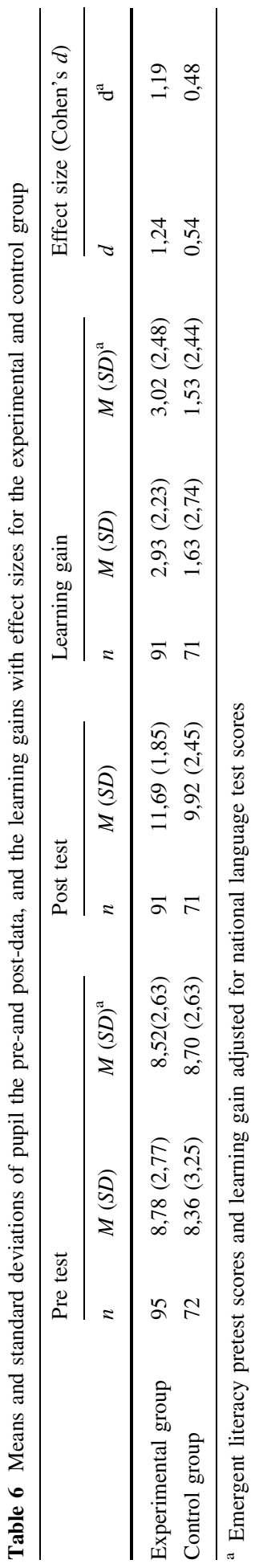


experimental group $M=2.93, S D=2.23, n=91$ were significantly higher than the learning gains of the pupils in the control group $M=1.63, S D=2.74, n=71$.

Emergent literacy proficiency of pupils learning with PictoPal

An ANCOVA with pre-post differences as dependent variable, class (1a, 1b, 2a, and 2b) as an independent variable, and scores on the national language test as a covariate showed a difference for class $F(3,86)=2,946, p<.05, \eta^{2}=.09$. The learning gains of 1a pupils $M=3.81, S D=2.28, n=18$ and the learning gains of $1 \mathrm{~b}$ pupils $M=3.72, S D=2.21$, $n=23$ were higher than the learning gains of $2 \mathrm{~b}$ pupils $M=2.09, S D=2.15, n=24$. Table 7 shows the means, standard deviations in the pre-and post test for the classes, and also the learning gains and effect sizes of the learning gains (Cohen's $d$ ).

As shown in Table 7 large effect sizes were obtained for the learning gains of pupils from the four classes. The learning gains of junior classes $1 \mathrm{a}$ and $1 \mathrm{~b}$ were found to differ significantly from the learning gain of pupils from senior class $2 \mathrm{~b}$. This difference might be explained as a result of a ceiling effect for the measurement of learning in classes $2 \mathrm{a}$ and $2 \mathrm{~b}$. Although the distributions of the pre- and posttest scores were approximately normal for classes $2 \mathrm{a}$ and $2 \mathrm{~b}$, the distributions showed that $30 \%$ of pupils from $2 \mathrm{a}$ and $32 \%$ from $2 \mathrm{~b}$ scored the maximum test score (14) compared to respectively 0 and $12 \%$ on the pretest. In comparison to junior pupils from $1 \mathrm{a}(n=18)$ and $1 \mathrm{~b}(n=23)$ with respectively 5 and $4 \%$ of pupils with the maximum score on post test, a relatively much higher percentage of pupils from classes $2 \mathrm{a}$ and $2 \mathrm{~b}$ scored the maximum score. This indicates that senior classes' pupils might have been able to score higher on the post test than the maximum tested score. The ceiling effect might have limited the measurement of the true posttest score and learning gains of pupils from classes $2 \mathrm{a}$ and $2 \mathrm{~b}$.

\section{Conclusions and discussion}

This study sought to explore the influence of teachers' perceptions of teaching/learning, technology and innovation on their technology integration of a technology-rich curriculum for emergent literacy and, in turn, the effects of integration on pupil learning outcomes. The findings of this study suggest that teacher perceptions about teaching/learning, technology and innovations can be related to the way in which teachers enacted the PictoPal. A developmental approach to teaching, perceiving technology as a tool for supporting learning, very positive expectations towards implementation of innovations, confidence in technology skills and perceiving support being provided by the principal in the face of work pressure are related to a high extent of technology integration. The findings in this study show that the teacher with a developmental approach to teaching perceived herself as a helper for pupils to construct meaning also integrated off computer activities to a higher extent than those who viewed themselves as facilitators who set conditions for learning. This finding is reminiscent of findings in a study by Hermans et al. (2008) which indicated that constructivist beliefs to learning favor technology integration. The developmental approach to teaching found in this study can be described as taking the role of helper and participating in childrens' activities (play) with computer generated products to encourage and enhance pupil use of literary products and related language. Although the teacher's developmental perspective on curriculum corresponded to substantial technology integration, the extent of integration did not necessarily influence pupil learning gains. 


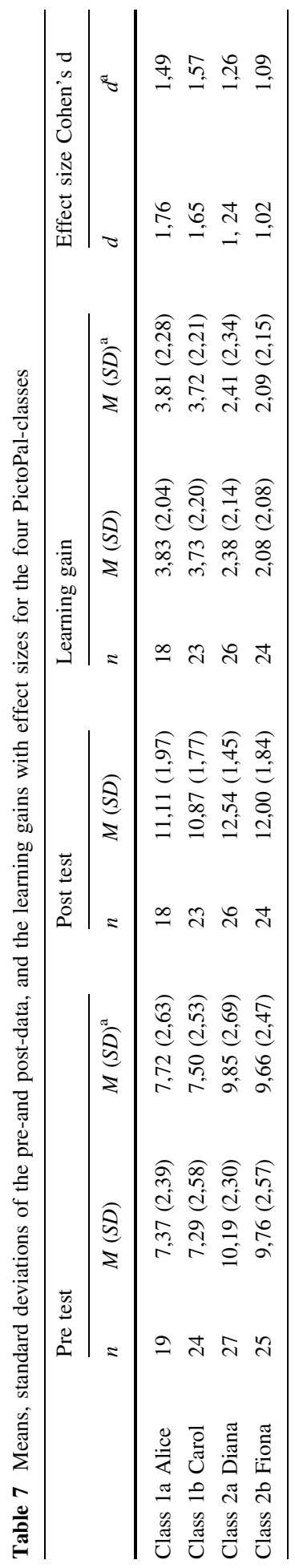


Interestingly, the study shows that a facilitative approach to teaching along with a moderate extent of technology integration still led to significant pupil learning gains.

The facilitative role taken by teachers is different and can be described as minimal (verbal) involvement in children's' activity (play), providing children with the tasks and tools to elicit autonomous activity (play).

Also, the finding that positive attitudes towards technology favorably influence technology integration reflects the findings of Hermans et al. (2008). Positive expectations about the success of implementation, that is expecting implementation to occur with some degree of investment of effort and time and expecting a congruency between pupils' skills and the innovative learning environment, were found in this study to relate to high technology integration. Concerns about technology skills related to low technology integration. Feeling daunted by the amount of effort needed for technology integration related to a mediocre integration. Since all teachers used the same intervention, it would appear that not an absolute measure of practicality, but a teacher's perception of how practical (or not) an innovation is (cf. Doyle and Ponder 1978) seems to have played an important role in influencing how these kindergarten teachers enacted the innovation.

Since all teachers perceived themselves as eager to learn about how to implement innovations and viewed PictoPal as an opportunity for learning, the 'willingness to learn' factor identified by Könings et al. (2006), had no differential impact on technology integration in this study. Technology integration seems to be influenced by teacher perceptions of principals' organizational support in the face of stressful working conditions such as time pressure. This finding is in congruence with the finding in the study of Inan and Lowther (2009) that perceived support provided by a principal positively influences teachers' technology integration. The finding in this study that kindergarten teachers working in the same school do not necessarily share the same perceptions on teaching/ learning contradicts the previously suggested relation between shared set of educational beliefs in particular school context as reported by Hermans et al. (2008).

The findings on pupil engagement indicate that pupils from senior classes do engage more in activities than pupils from junior classes. The difference on computer behavior found between junior and senior kindergarteners can be explained with developmentally related language use among senior dyads. Senior kindergarteners' language use during engagement in computer play activity is richer in vocabulary and more socially-oriented compared to junior kindergarteners. Also, senior kindergarteners are more familiar with each other as they have already spent one kindergarten year interacting with each other. A potential implication for on-computer activities involving junior kindergarteners is to combine children familiar with each other to stimulate peer interaction about computer literacy activity and subsequent symbolic play in off-computer activity (Pellegrini and Galda 1993). The finding that junior and senior kindergartener engagement during oncomputer activities increases over time indicates that junior kindergartener's skills to work within and enjoy PictoPal also grow during PictoPal implementation. A cross cases it appears that senior kindergarteners were helping each other more and engaged more in collaboration among peers during computer activities than junior kindergarteners. A possible explanation for this difference could be that senior kindergarteners are familiar with each other and that their teachers encourage cooperation in their classes. The junior kindergarteners spent more time and attention on actively engaging in the literacy activity on computer during the eight weeks, which could possibly explain why junior kindergarteners learning gains were higher than those of senior kindergarteners.

The finding that integration of on- and off-computer activities increases over time suggests that teacher integration of the activities improves during the first few weeks of 
PictoPal implementation. This finding along with the finding that the extent of pupil engagement increases during first weeks, implies that sustained and effective implementation of PictoPal can be reached, even if a teacher enacting PictoPal holds a facilitative (as opposed to developmental) approach to teaching and integrates technology initially to a low extent. Findings also indicate that the high pupil learning gains cannot be related to the high extent of technology integration of on- and off-computer activities. An explanation can be a ceiling effect for the measurement of learning in classes $2 a$ and $2 b$.

All studies have limitations. One is particularly notable in this study: testing emergent literacy. From the pre- and post-testing data, it appeared that a ceiling effect might have impaired the measurement of emergent literacy learning gains for the senior kindergarteners. Surprisingly, relatively more senior kindergarteners scored the maximum emergent literacy test score on a post test, compared to the scoring of the maximum score on the pretest. The ceiling effect in the sample of senior kindergarteners needs to be acknowledged and addressed in future research. Future research could also examine teachers working in different kindergarten contexts for example kindergarten teachers teaching non-native Dutch kindergarteners, and teachers using other language curricula than do teachers in this study. Also, future research could examine if the findings pertaining to developmental and non-developmental approach to teaching hold true for kindergarten teachers with these teaching approaches. While this study focused on teachers enacting a curriculum they were provided with, a next study could examine what happens when teachers construct together curriculum and enact it in classes. Collaboration between teachers on an innovative design is claimed by Fullan (2003) to create a sense of ownership and commitment to an innovative effort and a sustained use of an innovative curriculum. Future research could focus on effects of involving teachers in a supported joint creation of a curriculum for emergent literacy.

Open Access This article is distributed under the terms of the Creative Commons Attribution Noncommercial License which permits any noncommercial use, distribution, and reproduction in any medium, provided the original author(s) and source are credited.

\section{References}

Abrami, P. C., Poulsen, C., \& Chambers, B. (2004). Teacher motivation to implement an educational innovation: Factors differentiating users and non-users of cooperative learning. Educational Psychology, 24(2), 201-216.

Amante, L. (2007). The ICT at elementary school and kindergarten: Reasons and factors for the integration. Sísifo Educational Sciences Journal, 3, 49-62.

Cassell, J. (2004). Towards a model of technology and literacy development: Story listening systems. Applied Developmental Psychology, 25, 75-105.

Clements, D. H., Nastasi, B. K., \& Swaminathan, S. (1993). Young children and computers: Crossroads and directions from research. Research in Review Young Children, 48(2), 56-64.

Cooper, J. D. (1993). Literacy: Helping children construct meaning. Boston: Houghton Mifflin.

Cronin, L. L. (1991). Science teacher beliefs and their influence on curriculum implementation: Two case studies. Journal of Research in Science Teaching, 28(3), 235-250.

de Jong, M. T., \& Bus, A. G. (2004). The efficacy of electronic books in fostering kindergarten children's emergent story understanding. Reading Research Quarterly, 39(4), 378-393.

Doyle, W., \& Ponder, G. A. (1978). The practicality ethic in teacher decision-making. Interchange, 8, 1-12.

Ertmer, P. A. (1999). Addressing first- and second-order barriers to change: Strategies for technology integration. Educational Technology Research and Development, 47(4), 47-61.

Ertmer, P. A. (2005). Teacher pedagogical beliefs: The final frontier in our quest for technology integration? Educational Technology Research and Development, 53(4), 25-39.

Fullan, M. (2003). Change forces with a vengeance. New York: Routledge Falmer. 
Grossman, P., \& Thompson, C. (2008). Curriculum materials: Scaffolds for new teacher learning? Teaching and Teacher Education, 24, 2014-2026.

Hermans, R., Tondeur, J., van Braak, J., \& Valcke, M. (2008). The impact of primary school teachers' educational beliefs on the classroom use of computers. Computers \& Education, 51(4), 1499-1509.

Inan, F. A., \& Lowther, D. L. (2009). Factors affecting technology integration in K-12 classrooms: A path model. Educational Technology Research and Development. doi:10.1007/s11423-009-9132-y.

Koehler, M. J., \& Mishra, P. (2008). Introducing TPACK. In AACTE Committee on Innovation and Technology (Ed.), Handbook of technological pedagogical content knowledge for educators (pp. 3-29). New York, NY: Routledge.

Könings, K. D., Brand-Gruwel, S., \& van Merriënboer, J. J. G. (2006). Teachers' perspectives on innovations: Implications for educational design. Teaching and Teacher Education, 23, 985-997.

McKenney, S., \& Voogt, J. (2006). Emergent literacy test for 4-5 year olds. Enschede: University of Twente.

McKenney, S., \& Voogt, J. (2009). Designing technology for emergent literacy: The PictoPal initiative. Computers \& Education, 52, 719-729.

Miles, M. B., \& Huberman, A. M. (1994). Qualitative data analysis. Thousand Oaks: Sage Publications.

MoECS (Ministry of Education, Culture and Science). (1997). Nieuwe voorstellen kerndoelen basisonderwijs. [New proposals attainment targets primary education] http://www.minocw.nl/actueel/ persberichten/11618/Nieuwe-voorstellen-kerndoelen-basisonderwijs.html. Accessed 23 February 2010.

NAEYC (National Association for the Education of Young Children). (1996). Technology and young children-ages 3 through 8 . A position statement of the national association for the education of young children. http://www.naeyc.org/positionstatements. Accessed 21 November 2009.

NAEYC (National Association for the Education of Young Children). (2009). Developmentally appropriate practice in early childhood programs serving children from birth through age 8. A position statement of the national association for the education of young children. http://www.naeyc.org/ positionstatements. Accessed 21 November 2009.

Neuman, S. B., \& Roskos, K. (2005). Whatever happened to developmentally appropriate practice in early literacy? Young Children, 60(4), 22-27.

Niederhauser, D. S., \& Stoddart, T. (2001). Teachers' instructional perspectives and use of educational software. Teaching and Teaching Education, 17, 15-31.

Patton, M. Q. (2002). Qualitative research and evaluation methods. Thousand Oaks: Sage Publications.

Pellegrini, A. D., \& Galda, L. (1993). Ten years after: A reexamination of symbolic play and literacy research. Reading Research Quarterly, 28, 163-175.

Remillard, J. T. (1999). Curriculum materials in mathematics education reform. A framework for examining teachers' curriculum development. Curriculum Inquiry, 29(3), 315-342.

Remillard, J. T. (2000). Can curriculum materials support teachers learning? Two fourth-grade teachers' use of a new mathematics text. The Elementary School Journal, 100(4), 331-350.

Segers, E., \& Verhoeven, L. (2002). Multimedia support of early literacy learning. Computers in Education, 39(3), 207-221.

Segers, E., \& Verhoeven, L. (2005). Long-term effects of computer training of phonological awareness in kindergarten. Journal of Computer Assisted Learning, 21, 17-27.

Siraj-Blatchford, J., \& Whitebread, D. (2003). Supporting information and communications technology in the early years. Berkshire, UK: Open University Press.

Tondeur, J., Valcke, M., \& van Braak, J. (2008a). A multidimensional approach to determinants of computer use in primary education: Teacher and school characteristics. Journal of Computer Assisted Learning, 24(6), 494-506.

Tondeur, J., van Braak, J., \& Valcke, M. (2007). Curricula and the use of ICT in education. Two worlds apart? British Journal of Educational Technology, 38(6), 962-976.

Tondeur, J., van Keer, H., van Braak, J., \& Valcke, M. (2008b). ICT integration in the classroom: Challenging the potential of a school policy. Computers \& Education, 51(1), 212-223.

Turbill, J. (2001). A researcher goes to school: Using technology in the kindergarten literacy curriculum. Journal of Early Childhood Literacy, 1(3), 255-279.

Van Kuyk, J., \& Kamphuis, F. (2001). Verantwoording van de toetsen uit de pakketten Ruimte en Tijd, Taal voor Kleuters en Ordenen. [Accountability of the tests from the packages space and time, language for kindergarteners, and organizing] http://toetswijzer.kennisnet.nl/html/tg/3.pdf. Accessed 19 December 2009.

Van Scoter, J. (2008). The potential of IT to foster literacy development in kindergarten. In J. Voogt \& G. Knezek (Eds.), International handbook of information technology in education (pp. 149-161). London: Springer. 
Verhoeven, L., \& Aarnoutse, C. (1999). Tussendoelen beginnende geletetterdheid: Een leerlijn voor groep 1 tot en met 3. [Interim goals emergent literacy: a line in learning for grade 1 through 3]. Nijmegen: Expertisecentrum Nederlands.

Verseput, N. (2008). Picto-Integration test. Enschede: University of Twente.

Whittier, D. (2005). The teacher as software developer. Contemporary issues in technology and teacher education. http://www.citejournal.org/vol5/iss1/general/article2.cfm. Accessed 14 June 2011.

Zhao, Y., Pugh, K., Sheldon, S., \& Byers, J. L. (2002). Conditions for classroom technology innovations. Teachers College Record, 104(3), 482-515.

Amina Cviko research interest concerns the role of teachers in the implementation of technology-rich curricula for emergent literacy.

Susan McKenney research relates to exploring and supporting the interplay between curriculum development and teacher professional development, often related to language arts curricula.

Joke Voogt specializes in research on innovative use of information and communication technologies in the curriculum. 